\title{
Elicitation and Arrangement of Conceptual Meanings in the Lexicography of Less Documented Languages
}

Celestino Oriikiriza, Department of Linguistics, English Language Studies and Communication Skills, Makerere University, Kampala, Uganda (oriikiriza@chuss.mak.ac.ug/oriikiriza@yahoo.co.uk)

\begin{abstract}
The paper demonstrates how some of the dictionaries written in less documented languages, hardly meet the expectations of target users, due to some of the methods used in collecting and arranging meanings of words. The paper, therefore, explains the semantico-syntactic method of eliciting multiple conceptual meanings of words and the alphasyntactico-semantic mode of their arrangement in dictionary making. It concludes by showing how the two methods can lead to compilation of good dictionaries in less documented languages and how the dictionaries would be of benefit to the target users.
\end{abstract}

Keywords: ARRANGEMENT OF MEANINGS, CONCEPTUAL MEANINGS, DICTIONARY, LESS DOCUMENTED LANGUAGES, LEXICOGRAPHY

Opsomming: Onthulling en ordening van konseptuele betekenisse in die leksikografie van minder gedokumenteerde tale. In hierdie artikel word aangetoon dat woordeboeke vir tale wat nie goed gedokumenteer is nie, dikwels nie voldoen aan die verwagtinge van die teikengebruikers nie as gevolg van sommige metodes wat gebruik word in die versameling en ordening van betekenisonderskeidinge. Gevolglik word 'n uiteensetting gegee van die semanties-sintaktiese metode oor hoe om veelvuldige betekenisonderskeidinge van woorde te onthul en van die alfa-sintakties-semantiese metode oor hoe die ordening in woordeboeke kan geskied. Ter afsluiting word aangetoon hoe hierdie twee metodes tot die samestelling van goeie woordeboeke kan lei vir tale wat nie goed gedokumenteer is nie en hoe hierdie woordeboeke die teikengebruikers kan bevoordeel.

Sleutelwoorde: BETEKENISORDENING, KONSEPTUELE BETEKENIS, LEKSIKOGRAFIE, MINDER GEDOKUMENTEERDE TALE, WOORDEBOEK

\section{Introduction}

\section{Dictionaries: definition and importance}

A dictionary is a book in which words are listed alphabetically and their meanings, either in the same language or in another, and other information 
about them are given (Procter et al. 1995). Dictionaries shape the language, for instance, by presenting the standard form of a language to the dictionary user. They are used for reference in terms of meaning, spelling, pronunciation, grammar, synonyms, choice of words and for general information (e.g. geographical names and units of measure). Dictionaries are also language inventories. This paper traces the reasons why some of the dictionaries do not quite satisfy the user's needs on the particular aspect of meanings. It presents the semantico-syntactic method of elicitation of meanings of words and the alphasyntactico-semantic mode of arrangement of meanings as a solution to the problem.

\section{The Formal Stages of Compiling a Dictionary}

Cases abound where some language specialists or even enthusiasts write dictionaries without going through the formal stages of dictionary writing. In such cases, they collect words, and start defining their meanings. However, collection of words and definition of meanings are only part of the several formal stages of writing a dictionary. There is no doubt that a dictionary will achieve its objectives, if it is compiled following the formal stages of writing a dictionary.

Landau (1989) and Singh (1991) present the formal stages of compiling a dictionary. Broadly, the stages are: planning the dictionary, writing the dictionary and producing the dictionary. Revising the dictionary and abridging the dictionary are secondary stages of writing a dictionary. There are sub-phases under each of the steps. The stage of writing the dictionary is pertinent to a lexicographer who is writing a dictionary against the background of the need to record most basic meanings of words. Depending on the type of a dictionary (e.g. a general-purpose dictionary), the lexicographer needs to use a dictionary style manual that matches the intended goal, particularly on the method of eliciting multiple meanings of words and the arrangement of the meanings in a consistent order.

\section{Limitations of Meaning Elicitation and Arrangement in Dictionaries}

Taking the case of Uganda, the following backgrounds have influenced the writing of different dictionaries:

(i) Feelings of identity by speakers of minority languages, e.g., Lugungu language that is currently being recorded in a dictionary form.

(ii) The need to preserve the language, as in the case of Runyankore-Rukiga, which has had several dictionary projects.

(iii) The introduction of the thematic school curriculum. Uganda launched a school programme whereby mother tongues are used as mediums of in- 
struction for pupils in the lower primary school (P1-P3). The pupils learn about different topics, from which aspects of science, maths, social studies and grammar are highlighted. It is partly for ease of comprehension, because children learn better in the language they understand. It is also partly for building a foundation for the teaching of Ugandan languages in school, as plans are underway by the government to offer the languages as subjects of study in upper levels of school. In the upper levels, the indigenous languages are supposed to be studied alongside foreign languages, particularly English. Given this policy, some publishing houses have responded by writing and publishing dictionaries of various types in the approved languages. The dictionaries are written upon request by the government and others according to the good judgement of the publishing house.

(iv) Missionary activities: Missionary activities in Uganda saw the writing of different dictionaries in some local languages. The dictionaries were mainly bilingual for purposes of language learning by the missionaries and colonial agents, particularly educationists. For example, in 1917 and 1959, two dictionaries were published, namely, a Luganda-French dictionary and a Runyankore-Rukiga-English and English-Runyankore-Rukiga dictionary written by Le Veux and Taylor respectively.

The objectives and uses of the dictionaries cited above are good because they aim at the documentation of languages, finding alternative ways of mediums of instruction and solving the communication gap.

However, the most intriguing problem comes when such dictionaries cannot fulfil the expectations of the users in schools, or in ordinary situations, and if they cannot be judged as proper reflections of what is in the language. This is what Kiango (2000: 4) alludes to by noting that early dictionaries compiled by the missionaries and the colonial administrators, were not compiled with a native speaker in mind as the prime user ... these dictionaries were not aimed at being complete records of the languages concerned and up to this time no such records exist.

With respect to meanings and their arrangement in a dictionary, a comparative analysis of a Ugandan language dictionary with an English dictionary (published by a reputable house), results into noticeable differences. The dictionaries in English tend to have multiple meanings of words than dictionaries in most Ugandan languages. They also tend to have meanings of words arranged in a consistent order than their counterparts referred to above. The difference is caused by the methods used for generating meanings of words and arranging the meanings in a consistent order.

Corpus-driven methods can generate multiple meanings. They can also lead to consistent arrangement of the meanings in dictionary form than fieldwork-based methods. However, corpus-driven methods easily work in welldocumented languages where written corpus is readily available than in less documented languages where it is not. For example, the level of documentation of Ugandan languages is very low compared to that of English. 
As a result, dictionaries in well-documented languages are much more likely to have a higher coverage of meanings of words than dictionaries in less documented languages. Oriikiriza (2011) cites an example of make (v.) in several English dictionaries; okukora (v.), a Runyankore-Rukiga word for 'work', 'do', 'make' in some Runyankore-Rukiga dictionaries; and la (v.), a Kiswahili word for 'eat' in some Kiswahili dictionaries. The work indicates that Summers et al. (2003), an advanced learner's dictionary, has 27 main meanings of the word make, and Soanes (2001), which is a pocketsize volume, has 10 main meanings of the word. In the case of the Runyankore-Rukiga example okukora (v.), the work indicates that the latest and standard dictionary among the ones that are cited for Runyankore-Rukiga is Oriikiriza (2007). It is described as a general-purpose dictionary with 4 main meanings of okukora (v.). For Kiswahili, TUKI (1981), the work describes it as a general-purpose Kiswahili dictionary, and that it records 8 main meanings for $l a$. Therefore, basing on these examples, a general-purpose dictionary in a Bantu language (e.g. Runyankore-Rukiga and Kiswahili) has a coverage of meanings that is equivalent or almost equivalent to that of a pocketsize English dictionary. This difference is attributed to the methods of obtaining the meanings.

Use of informants (fieldwork) and the lexicographer's knowledge of the language are the main methods of generating meanings of words and arranging them in dictionary form in less documented languages, e.g. Bantu, as compared to the corpus-driven methods in well-documented languages. In the former case, the methods rely on memory and so are prone to situations where the informant or lexicographer cannot recall most of the meanings of a word. Secondly, the informant or the lexicographer sequences meaning of words according to the order in which he/she knows them. This sequence is subjective since the dictionary target users do not necessarily store meanings of words in the same order according to their innate knowledge of the meanings. In order to solve the problem, the corpus-driven methods of generating meanings of words and arranging meanings in a consistent order would substitute the fieldwork methods. However, they are affected by lack of sufficient written materials to generate the corpus. In this regard, there is need to develop other non-corpusdriven methods that can be used. One of the methods being proposed in this paper is the semantico-syntactic method of elicitation of conceptual meanings of words and the alphasyntactico-semantic mode of arrangement of the meanings.

4. The Semantico-syntactic Method of Elicitation of Conceptual Meanings of Words and the Alphasyntactico-semantic Mode of Arrangement of the Meanings

\subsection{Classification of Meanings}

Lexical meaning can be defined as the sense, reference, usage and utterance of 
a word. Sense in this context refers to the basic meaning of a word, while reference refers to the extended meanings. The usage meaning is associated with the social usage of the word. These kinds of meanings can be explained using an example of sit (v.), 'to rest or relax on a chair or seat'. As a basic meaning, it is therefore the sense. In a sentence such as The committee sits tomorrow, sit means 'to hold a meeting'. This is an extended meaning derived from the sense. It should be noted that words may have meanings resulting from usage according to region, medium, attitude, status, field (of practice, e.g. legal), temporal perspective (e.g. obsolete, archaic), situation (e.g. formal, informal, elevated style, slang), etc. These are usage meanings. They may also have meanings resulting from the speech act with which the word is used. The meanings in this case are referred to as utterance meanings.

Taking the example of sit, Summers et al. (2003) records as British English (i.e. regional/geographical usage) its meaning of 'taking an exam'. It also records it as having a specific imperative meaning, 'when used to tell a dog to sit in an upright position'. A command in this case is an utterance meaning.

For sense and reference meaning in particular, it is suffices to say that sense results from the basic pattern with which a word is used and reference meaning results from a different entity with which a word is used. Therefore, the basic pattern of sit is [something sits on something], e.g., The child is sitting on a mat. In this pattern, sit denotes the basic meaning, i.e. 'resting your body in a chair or seat'. It gets a reference meaning when the entities in the same pattern are varied. For example, in The building is sitting on an acre piece of land, sit means 'to be positioned or found in a particular place'. This sentence is of the same pattern as the one above, but the entities being interrelated by the verb, namely 'building' and 'acre piece of land' are different from those in The child is sitting on a mat. The variation in entities results into a different meaning of the verb.

All these kinds of meanings outlined above need to be compiled in a dictionary, particularly a general-purpose dictionary. The sense and reference meanings are collectively known as conceptual meanings, while the usage and speech act meanings are known as interpersonal meanings. This paper only discusses the elicitation and arrangement of conceptual meanings (sense and reference), using the semantico-syntactic method and the alphasyntactico-semantic mode respectively (see 4.3 below). The semantico-syntactic method of elicitation of meanings of words is based on the situation-role theory of meaning (Kiingi 2008; Kiingi 2009). The method can be used to elicit conceptual meanings of words, i.e. senses and reference meanings. The alphasyntactico-semantic mode of arrangement of the meanings is partly based on the situation-role theory, and partly on the alphabetical mode of arrangement. Both methods will be exemplified later on; however, the situation-role theory from which they are derived is explained below. 


\subsection{The Situation-Role Theory of Meaning}

The situation-role theory of meaning is a modified version of the semantic-role theory of meaning. The theory postulates the following: situations, semantic categories and semantic-roles.

\subsubsection{Situation}

A situation is a state-of-affairs expressed in a sentence.

\subsubsection{Semantic categories}

Semantic categories are entities that perform the roles in the situations. Table I provides an outline of these categories and their corresponding examples of entities.

Table I: Semantic Categories

\begin{tabular}{|c|c|}
\hline $\begin{array}{l}\text { GENERAL SEMANTIC } \\
\text { CATEGORY (IN NAME } \\
\text { AND ABBREVIATION) }\end{array}$ & EXAMPLES OF ENTITIES IN THE CATEGORY \\
\hline (1) human (h) & Peter, John, he, she, they \\
\hline (2) animate (b) & dog, giraffe, institution or organisation \\
\hline (3) concrete (r) & chair, pot, car, key, door, plant, animal, building \\
\hline (4) event (e) & write, dance, beg, open, study, pay \\
\hline (5) abstract (a) & $\begin{array}{l}\text { light, sound, heat, energy, a non-physical report as } \\
\text { opposed to a physical (i.e. concrete) report, and a school } \\
\text { (as an institution) }\end{array}$ \\
\hline (6) state, i.e. quality (q) & happy, sick, sad \\
\hline (7) quantity, i.e. group (g) & sets of things, e.g. team, pair of shoes, group \\
\hline (8) number (n) & $\begin{array}{l}\text { numerical objects, e.g. once a year, twice in a week, } \\
\text { forty days, two billion }\end{array}$ \\
\hline (9) space (l) & spaces, e.g. up, down, inside, town, Kampala, London \\
\hline (10) time (t) & $\begin{array}{l}\text { temporal objects, e.g., today, tomorrow, yesterday, a } \\
\text { fortnight ago }\end{array}$ \\
\hline
\end{tabular}

\subsubsection{Semantic roles}

Semantic roles refer to the roles performed in situations as indicated in the Table II below. 
Table II: Semantic Roles

\begin{tabular}{|c|c|c|}
\hline SEMANTIC-ROLE & $\begin{array}{l}\text { ABBREVIA- } \\
\text { TION }\end{array}$ & EXAMPLE \\
\hline $\begin{array}{l}\text { (1) Volitional, Affected and } \\
\text { Dynamic bearer }\end{array}$ & $\mathrm{V}$ & The students went to class. \\
\hline $\begin{array}{l}\text { (2) Non-volitional, Affected } \\
\text { and Dynamic bearer }\end{array}$ & B & The hunter killed an animal. \\
\hline $\begin{array}{l}\text { (3) Effected: outcome or result } \\
\text { in a situation }\end{array}$ & $\mathrm{X}$ & $\begin{array}{l}\text { He wrote a letter. } \\
\text { He made a pot from clay. }\end{array}$ \\
\hline $\begin{array}{l}\text { (4) Volitional Affected Non- } \\
\text { dynamic bearer }\end{array}$ & $\mathrm{W}$ & The driver stood near the car. \\
\hline $\begin{array}{l}\text { (5) Non-Volitional, Non- } \\
\text { affected and Non-dynamic } \\
\text { bearer }\end{array}$ & Q & $\begin{array}{l}\text { The clothes are dry. } \\
\text { The door is open. }\end{array}$ \\
\hline $\begin{array}{l}\text { (6) Follower: a situation that } \\
\text { follows another }\end{array}$ & $\mathrm{F}$ & $\begin{array}{l}\text { The substance changed from a liquid to a } \\
\text { gas. (Larson and Segal 1995: 482) }\end{array}$ \\
\hline $\begin{array}{l}\text { (7) Direction: the category } \\
\text { faced in a situation }\end{array}$ & $\mathrm{D}$ & The school is opposite the mosque. \\
\hline $\begin{array}{l}\text { (8) Reference: the category } \\
\text { referred to in a situation }\end{array}$ & $\mathrm{R}$ & $\begin{array}{l}\text { (a) They are at home. } \\
\text { (b) The exam starts at nine. }\end{array}$ \\
\hline $\begin{array}{l}\text { (9) Source: the category at the } \\
\text { beginning of a situation }\end{array}$ & S & $\begin{array}{l}\text { (a) The substance changed from a liquid to } \\
\text { a gas. (Larson and Segal 1995: 482) } \\
\text { (b) The inheritance passed from Jill to } \\
\text { Kate. (Larson and Segal 1995: 482) }\end{array}$ \\
\hline $\begin{array}{l}\text { (10) Mediate: the category be- } \\
\text { tween two categories in a } \\
\text { situation }\end{array}$ & M & They travelled to London by train. \\
\hline $\begin{array}{l}\text { (11) Goal: the category at the } \\
\text { end of a situation }\end{array}$ & G & $\begin{array}{l}\text { (a) The substance changed from a liquid to } \\
\text { agas. (Larson and Segal 1995: 482) } \\
\text { (b) The inheritance passed from Jill to } \\
\text { Kate. (Larson and Segal 1995: 482) }\end{array}$ \\
\hline $\begin{array}{l}\text { (12) Possessum: the category } \\
\text { possessed in a situation }\end{array}$ & $\mathrm{H}$ & $\begin{array}{l}\text { We have little food. } \\
\text { Harriet owns a cat. (Brown and Miller } \\
\text { 1980: 309) }\end{array}$ \\
\hline $\begin{array}{l}\text { (13) Comitative: the category } \\
\text { accompanying another in } \\
\text { a situation }\end{array}$ & $\mathrm{J}$ & The bride walked with the groom. \\
\hline
\end{tabular}




\begin{tabular}{|l|c|l|}
\hline $\begin{array}{c}\text { (14) Stimulus: The category } \\
\text { perceived in a situation }\end{array}$ & $\mathrm{T}$ & $\begin{array}{l}\text { We saw a dog. } \\
\text { We heard birds singing in the tree. }\end{array}$ \\
\hline $\begin{array}{c}\text { (15) Volitional entity gen- } \\
\text { erator }\end{array}$ & $\mathrm{I}$ & $\underline{\text { He wrote a letter with a pen. }}$ \\
\hline $\begin{array}{c}\text { (16) Non-Volitional entity } \\
\text { generator }\end{array}$ & $\mathrm{N}$ & The machine makes bricks. \\
\hline (17) Volitional affector & $\mathrm{Z}$ & $\underline{\text { They elected him chairman. }}$ \\
\hline (18) Non-volitional affector & $\mathrm{E}$ & $\begin{array}{l}\text { (a) Ali gave } \text { Fatuma a book. } \\
\text { (b) It gave us a big problem. }\end{array}$ \\
\hline $\begin{array}{c}\text { (19) Volitional recipient } \\
\text { (20) Non-volitional recipient }\end{array}$ & $\mathrm{O}$ & $\begin{array}{l}\text { Ali gave the door a kick. (I.e. to give sth. } \\
\text { sth. })\end{array}$ \\
\hline (21) Volitional event causer & A & $\underline{\text { Peter opened the door. }}$ \\
\hline $\begin{array}{c}\text { (22) Non-volitional event } \\
\text { causer }\end{array}$ & $\mathrm{C}$ & $\underline{\text { The key opened the door. }}$ \\
\hline
\end{tabular}

The following proofs are made from the situation-role theory:

(i) General structures which specify the place of a semantic-role in a sentence. The structures are called well-formed formulae (wff) as shown in the first column of Table III below.

Table III: Well-formed Formulae for Semantic-Roles

\begin{tabular}{|l|l|l|}
\hline $\begin{array}{l}\text { Well-formed formulae } \\
\text { (with } \theta \text { [theta] standing } \\
\text { for semantic-role and } \varepsilon \\
\text { [epsilon] for semantic } \\
\text { category) }\end{array}$ & $\begin{array}{l}\text { Entities playing the seman- } \\
\text { tic roles (underlined) }\end{array}$ & $\begin{array}{l}\text { Sentence expressed in terms of } \\
\text { semantic-roles and semantic } \\
\text { categories indicated in Table I } \\
\text { \& II }\end{array}$ \\
\hline$[\theta \varepsilon]$ & The door opened. & $\mathrm{Br}$ \\
\hline$\left[\theta \varepsilon_{1} \theta \varepsilon_{2}\right]$ & $\underline{\text { He opened the door. }}$ & $\mathrm{Ah} \mathrm{Br}$ \\
\hline$\left[\theta \varepsilon_{1} \theta \varepsilon_{2} \theta \varepsilon_{3}\right]$ & $\underline{\text { He opened the door with a }}$ & $\mathrm{Ah} \mathrm{Br}_{1} \operatorname{Rr}_{2}$ \\
\hline
\end{tabular}

\section{(ii) Semantic-Role Patterns}

Just as there are (basic) sentence patterns, there are also semantic-role patterns as shown below. 
Table IV: Semantic-Role Patterns

\begin{tabular}{|c|c|}
\hline $\begin{array}{l}\text { Semantic-role } \\
\text { Pattern }\end{array}$ & Explanation and example \\
\hline$\Omega$ & $\begin{array}{l}\text { The symbol is read as omega. It stands as a semantic-role pattern } \\
\text { for situations involving the following roles: V (He laughed), B (The } \\
\text { door opens, The ball reddens), X (The ice is melting) }\end{array}$ \\
\hline$\Psi$ & $\begin{array}{l}\text { The symbol is read as psi. It stands as a semantic-role pattern } \\
\text { for situations involving the following roles: } \mathrm{V} \text { (He turned a traitor), } \\
\mathrm{B} \text { (The ball becomes red), } \mathrm{X} \text { (The children are playing well); } \mathrm{W} \text { (Ali is a } \\
\text { doctor), } \mathrm{Q} \text { (The ball is red) }\end{array}$ \\
\hline $\mathrm{K}^{\prime} \Psi$ & $\begin{array}{l}\text { The symbol } \mathrm{K}^{\prime} \text { is read as kei prime. It combines with psi to form a } \\
\text { combinational pattern in which the following roles occur: a causer } \\
\text { of a causer }\left(\mathrm{K}^{\prime}\right) \text { and any of the } \Psi \text { roles. Example: They painted the } \\
\text { door red. This situation presupposes 'The door is red', 'The door } \\
\text { becomes red' and 'They made the door red'. It can be expressed in } \\
\text { terms of the semantic-roles and semantic categories as Ah [Br Gq]. }\end{array}$ \\
\hline$\Psi \Phi$ & $\begin{array}{l}\text { The symbol } \Phi \text { is read as phi. It stands with psi to form a combi- } \\
\text { national pattern involving any of the } \Psi \text { and } \Phi \text { roles. The roles in the } \\
\text { latter case are F, D, R; S, M, G; H, J, T. Example: The children went to } \\
\text { school. Bh } \mathrm{R}_{1}\end{array}$ \\
\hline $\mathrm{K} \Psi$ & $\begin{array}{l}\text { This is a combinational pattern involving a causer }(\mathrm{K}) \text { and any of } \\
\text { the } \Psi \text { roles. The } \mathrm{K} \text { roles are I, N; Y, Z; O, E; A, C. Example: } \underline{I o h n} \\
\text { killed a dog. Ah } \mathrm{Bb}\end{array}$ \\
\hline $\mathrm{K} \Psi \Phi$ & $\begin{array}{l}\text { This is a combinational pattern involving three semantic-roles, i.e., } \\
\text { any of the } \mathrm{K}, \Psi \text { and } \Phi \text {. Example: Iane knitted a sweater for John. } \mathrm{Ih}_{1} \mathrm{Xr} \\
\mathrm{Oh}_{2}\end{array}$ \\
\hline $\mathrm{K}^{\prime} \mathrm{K} \Psi$ & $\begin{array}{l}\text { This is a combinational pattern involving three roles, i.e., any of the } \\
\mathrm{K}^{\prime}, \mathrm{K} \text { and } \Psi \text { roles respectively. Example: } \underline{\text { He opened the door with a }} \\
\text { key. } \mathrm{Ah} \mathrm{Br}_{1} \mathrm{Rr}_{2}\end{array}$ \\
\hline
\end{tabular}

(iii) Syntactic-role patterns

The term syntactic-role patterns is akin to sentence patterns. Except that, the syntactic-role patterns do not correspond exactly to the sentence patterns. The degree of correspondence can be seen in the examples in Table V.

Table V: Degree of correspondence between syntactic-role patterns and sentence patterns

\begin{tabular}{|l|l|}
\hline Syntactic-role Patterns & Sentence Patterns \\
\hline S (Subject): The door opens. & SV (Subject + Verb): The door opens. \\
\hline $\begin{array}{l}\text { SN (Subject + Neutral element): } \underline{\text { The ball }} \\
\text { is red. }\end{array}$ & $\begin{array}{l}\text { SVC (Subject + Verb + Complement): } \underline{\text { Ali }} \text { is } \\
\text { a doctor. }\end{array}$ \\
\hline
\end{tabular}




\begin{tabular}{|c|c|}
\hline $\begin{array}{l}\mathrm{SCN}(\text { Subject }+ \text { Constrained object }+\mathrm{Neu}- \\
\text { tral complement): They painted the door } \\
\text { red. }\end{array}$ & $\begin{array}{l}\text { SVA (Subject + Verb + Adverbial): } \\
\text { The children went to school. }\end{array}$ \\
\hline $\begin{array}{l}\text { SF (Subject + Free object): The children went } \\
\text { to school LHe saw a dog. }\end{array}$ & $\begin{array}{l}\text { SVO (Subject + Verb + Object): } \\
\text { He killed a dog. }\end{array}$ \\
\hline $\begin{array}{l}\text { SC (Subject + Constrained object): } \underline{\text { He killed }} \\
\text { a dog. }\end{array}$ & $\begin{array}{l}\text { SVOC (Subject + Verb + Object + Comple- } \\
\text { ment): They elected him president. }\end{array}$ \\
\hline $\begin{array}{l}\text { SCF (Subject + Constrained object + Free } \\
\text { object): [ane knitted a sweater for John. }\end{array}$ & $\begin{array}{l}\text { SVOA (Subject + Verb + Object + Adver- } \\
\text { bial): [ane knitted a sweater for John. }\end{array}$ \\
\hline $\begin{array}{l}\text { SCC }(\text { Subject }+ \text { Constrained object }+ \text { Con- } \\
\text { strained object }): \text { He opened the door with a } \\
\text { key. }\end{array}$ & $\begin{array}{l}\text { SVOO }(\text { Subject }+ \text { Verb }+ \text { Object }+ \text { Object }): \\
\text { He opened the door with a key. }\end{array}$ \\
\hline
\end{tabular}

There is a mismatch in the placement of the situations. What is a complement in the sentence patterns is a neutral element in the syntactic-role patterns, if it expresses a state, or quality. This is one of the differences between syntacticrole patterns and sentence patterns.

(iv) Semantico-syntactic Isomorphism

The explanation above systematises syntactic-role patterns and semantic-role patterns. The juxtaposition below shows that there is a one-to-one correspondence between semantic-role patterns and syntactic-role patterns, signified by the symbol $\cong$. In this way, the patterns can be called semantico-syntactic patterns, or syntactico-semantic patterns:

(1) $[\Omega] \cong S$

(2) $[\Psi] \cong S \mathrm{~S}$

(3) $\left[\mathrm{K}^{\prime} \Psi\right] \cong \mathrm{SCN}$

(4) $[\Psi \Phi] \cong \mathrm{SF}$

(5) $[\mathrm{K} \Psi] \cong \mathrm{SC}$

(6) $[\mathrm{K} \Psi \Phi] \cong \mathrm{SCF}$

(7) $\left[\mathrm{K}^{\prime} \mathrm{K} \Psi\right] \cong \mathrm{SCC}$

(v) Phrasal Categorial Patterns

Semantico-syntactic patterns can be expressed in terms of phrasal categorial patterns as demonstrated in Table VI.

Table VI: Phrasal Categorial Patterns

\begin{tabular}{|c|l|l|}
\hline $\begin{array}{l}\text { Semantic-role } \\
\text { pattern }\end{array}$ & $\begin{array}{l}\text { Examples of a semantic-role } \\
\text { playing entity (underlined) }\end{array}$ & $\begin{array}{l}\text { Phrasal-categorial patterns of the } \\
\text { entities }\end{array}$ \\
\hline$\Omega$ & $\underline{\text { The door opens. }}$ & N" (Noun Phrase) \\
\hline$\Psi$ & $\underline{\text { Ali is a doctor. }}$ & $\begin{array}{l}\text { N" N" (Noun Phrase, Noun Phrase) } \\
\text { N" A" (Noun Phrase, Adjective Phrase) }\end{array}$ \\
\hline
\end{tabular}




\begin{tabular}{|c|c|c|}
\hline$K^{\prime} \Psi$ & $\begin{array}{l}\text { They elected him president. } \\
\text { They painted the door red. }\end{array}$ & $\begin{array}{l}\text { N" N" N" (Noun Phrase, Noun Phrase, } \\
\text { Noun Phrase) } \\
\text { N" N" A" (Noun Phrase, Noun Phrase, } \\
\text { Adjective Phrase) }\end{array}$ \\
\hline$\Psi \Phi$ & $\begin{array}{l}\text { He came yesterday. } \\
\text { The cat is under the table. }\end{array}$ & $\begin{array}{l}\text { N" Adv" (Noun Phrase, Adverb Phrase) } \\
\text { N" P" (Noun Phrase, Prepositional } \\
\text { Phrase) }\end{array}$ \\
\hline $\mathrm{K} \Psi$ & $\begin{array}{l}\text { He opened the door. } \\
\underline{\text { He was hit by a bullet. }} \\
\text { He came to show me the report. }\end{array}$ & $\begin{array}{l}\text { N" N" (Noun Phrase, Noun Phrase) } \\
\text { N" P" (Noun Phrase, Prepositional } \\
\text { Phrase) } \\
\text { N" S' (Noun Phrase, Clause) }\end{array}$ \\
\hline $\mathrm{K} \Psi \Phi$ & $\begin{array}{l}\text { He wrote the report well. } \\
\underline{\text { He gave the book to me. }}\end{array}$ & $\begin{array}{l}\text { N" N" Adv" (Noun Phrase, Noun } \\
\text { Phrase, Adverb Phrase) } \\
\text { N" N" P" (Noun phrase, Noun Phrase, } \\
\text { Prepositional Phrase) }\end{array}$ \\
\hline$K^{\prime} K \Psi$ & $\begin{array}{l}\text { He gave me a book. } \\
\text { The venture caused me trouble. } \\
\text { He opened the door with a } \\
\text { key. } \\
\text { They elected him as their rep- } \\
\text { resentative. }\end{array}$ & $\begin{array}{l}\text { N" N" N" (Noun Phrase, Noun Phrase, } \\
\text { Noun Phrase) } \\
\text { N" N" P" (Noun Phrase, Noun Phrase, } \\
\text { Prepositional Phrase) } \\
\text { N" N" S' (Noun Phrase, Noun Phrase, } \\
\text { Clause) }\end{array}$ \\
\hline
\end{tabular}

\subsection{Application of the Situation-Role Theory in Meaning Elicitation and Arrangement}

The corpus-driven method is the conventional approach for elicitation of meanings of words. It is also the conventional approach for the arrangement of meanings of words, particularly in the arrangement of meanings of words by order of their frequency. However, it is not quite viable in the dictionary compilation of less documented languages, since it relies on sufficient written materials that are not easy to find in a less documented language. Oriikiriza (2011) argues that multiple meanings can be easily elicited and consistently arranged using the semantico-syntactic method and the alphasyntactico-semantic mode respectively, without the written materials of a language. The methods are mainly based on the Situation-Role Theory of meaning (Kiingi 2008; Kiingi 2009), and largely depend on the grammatical structure of language. They are stated as follows:

\section{STEP 1:}

For a given word, find out a sentence (i.e. situation) in which its basic (i.e. core) meaning is applied. The sentence is meant to enable us to predict other meanings of the target word in STEP 2 and 3. 
STEP 2a:

Find the semantic-role patterns with which the word is used, by constructing sentences based on the ascending complexity of syntactico-semantic patterns.

STEP 2b:

Using semantic category switching and semantic category variation, construct more sentences.

STEP 3a:

Formalise the sentences (i.e. express the sentences in terms of semantic-roles and semantic categories).

STEP 3b:

Investigate the meaning of the word by looking at each of the example sentences in terms of its formalisation.

STEP 4:

Order the meanings according to:

(i) ascending complexity of semantico-syntactic patterns (i.e. valency);

(ii) ascending complexity of semantic categories;

(iii) alphabetical place of sub-entries; and

(iv) chronological order of the categories of usage labels.

For example, given a word such as put, one proceeds as follows:

STEP 1

Find out a sentence, in which the basic meaning of a word is applied, e.g., $\mathrm{He}$ put the book on the table. This helps one to know where to start from in terms of the augmented valency and reduced valency, i.e. the increasing and decreasing complexity of the semantico-syntactic patterns shown below:

(1) $\Omega \quad \cong S$

(2) $\psi \cong \mathrm{SN}$

(3) $\mathrm{K}^{\prime} \Psi \cong \mathrm{SCN}$

(4) $\Psi \Phi \cong S F$

(5) $\mathrm{K} \Psi \cong \mathrm{SC}$

(6) $\mathrm{K} \Psi \Phi \cong \mathrm{SCF}$

(7) $\mathrm{K}^{\prime} \mathrm{K} \Psi \cong \mathrm{SCC}$

They are related as follows in terms of complexity: (1) represents a single semantic-role pattern, (3) is derived from (2), (4) is derived from (2), (5) is derived from (2), (6) is derived from (4), and (7) is derived from (5). The derivation is indicative of the increasing and decreasing order of complexity of the semantico-syntactic patterns. The sentence He put the books on the table fits the 
pattern $\mathrm{K} \Psi \Phi \cong \mathrm{SCF}$. The pattern is reducible to $\Psi \Phi \cong \mathrm{SF}$ and finally to $\Omega \cong \mathrm{S}$. Sentences that are likely to fit these patterns can be constructed using put as shown in Table VII, number (6) under STEP 2a. What should be noted is that according to the information in the Table VII, put does not fit in other patterns, i.e. (1)-(5) and (7) as indicated with dashes in the extreme right column of the Table.

\section{STEP 2 (a)}

Find the semantic-role with which the target word is used. This is done by constructing sentences based on the phrasal patterns in the ascending complexity of syntactico-semantic patterns, using that word. Examples are shown in Table VII.

Table VII: Construction of Sentences

\begin{tabular}{|c|c|c|}
\hline Syntactico-semantic pattern & Sentence & Semantic-role \\
\hline $\begin{array}{l}\text { (1) } \Omega \cong \mathrm{S} \rightarrow(\mathrm{N} "), \text { e.g., The ball } \\
\text { reddens. }\end{array}$ & $\begin{array}{l}\text { This pattern is not applicable } \\
\text { to put. }\end{array}$ & - \\
\hline $\begin{array}{l}\text { (2) } \Psi \cong \mathrm{SN} \rightarrow \\
(\mathrm{N} " \mathrm{~N} "), \text { e.g., Ali is a doctor. } \\
\left(\mathrm{N} " \mathrm{~A}^{\prime \prime}\right) \text {, e.g., The room is } \\
\text { dirty. }\end{array}$ & $\begin{array}{l}\text { This pattern is not applicable } \\
\text { to } p u t \text {. } \\
\text { This pattern is not applicable } \\
\text { to } \text { put. }\end{array}$ & $\begin{array}{l}- \\
-\end{array}$ \\
\hline $\begin{array}{l}\text { (3) } \mathrm{K}^{\prime} \Psi \cong \mathrm{SCN} \rightarrow \\
\left(\mathrm{N}^{\prime \prime} \mathrm{N} " \mathrm{~N} "\right), \text { e.g., They elected } \\
\text { him president. } \\
\text { (N" N" A), e.g., They made } \\
\text { the road wide. }\end{array}$ & $\begin{array}{l}\text { This pattern is not applicable } \\
\text { to put. } \\
\text { This pattern is not applicable } \\
\text { to } p u t \text {. }\end{array}$ & $\begin{array}{l}- \\
-\end{array}$ \\
\hline $\begin{array}{l}\text { (4) } \Psi \Phi \cong \mathrm{SF} \rightarrow \\
(\mathrm{N} " \text { Adv"), e.g., The women } \\
\text { were walking slowly. } \\
\left(\mathrm{N} " \mathrm{P}^{\prime \prime}\right) \text {, e.g., The children } \\
\text { were sitting on a mat. }\end{array}$ & $\begin{array}{l}\text { This pattern is not applicable } \\
\text { to } p u t \text {. } \\
\text { This pattern is not applicable } \\
\text { to } \text { put. }\end{array}$ & $\begin{array}{l}- \\
-\end{array}$ \\
\hline $\begin{array}{l}\text { (5) } \mathrm{K} \Psi \cong \mathrm{SC} \rightarrow \\
\left(\mathrm{N}^{\prime \prime} \mathrm{N} "\right), \text { e.g., He shattered the } \\
\text { window. } \\
\left(\mathrm{N}^{\prime \prime} \mathrm{P} "\right), \text { e.g., The visitors } \\
\text { knocked at the door. } \\
\left(\mathrm{N}^{\prime \prime} \mathrm{S}^{\prime}\left[\mathrm{Cl}_{\text {that, }} \mathrm{Cl}_{\varnothing} \text { to }, \mathrm{Cl}_{\text {to }}\right.\right. \\
\left.\left.\mathrm{Cl}_{\text {wh-, }} \mathrm{Cl}_{- \text {ing, }} \text { and } \mathrm{Cl}_{-\mathrm{ed}},\right]\right) \\
\text { These stand for that clause, } \\
\text { infinitive clause, zero infini- } \\
\text { tive clause, wh-clause, -ing } \\
\text { clause and past participle }\end{array}$ & $\begin{array}{l}\text { This pattern is not applicable } \\
\text { to put. } \\
\text { This pattern is not applicable } \\
\text { to put. } \\
\text { This pattern is not applicable } \\
\text { to put. }\end{array}$ & $\begin{array}{l}- \\
- \\
-\end{array}$ \\
\hline
\end{tabular}




\begin{tabular}{|c|c|c|}
\hline $\begin{array}{l}\text { clause respectively; for ex- } \\
\text { ample, He wanted me to come } \\
\text { in the case of the infinitive } \\
\text { clause. }\end{array}$ & & \\
\hline $\begin{array}{l}\text { (6) } \mathrm{K} \Psi \text { } \Phi \cong \mathrm{SCF} \rightarrow \\
\left(\mathrm{N}^{\prime \prime} \mathrm{N} " \mathrm{Adv} "\right) \\
\left(\mathrm{N}^{\prime \prime} \mathrm{N}^{\prime \prime} \mathrm{P}\right)\end{array}$ & $\begin{array}{l}\text { He put the box } \frac{\text { down. }}{\text { The pupil put the books on the }} \\
\text { table. }\end{array}$ & 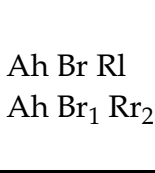 \\
\hline 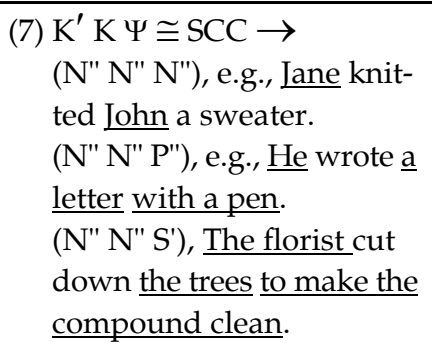 & $\begin{array}{l}\text { This pattern is not applicable } \\
\text { to put. } \\
\text { This pattern is not applicable } \\
\text { to put. } \\
\text { This pattern is not applicable } \\
\text { to put. }\end{array}$ & $\begin{array}{c}- \\
- \\
-\end{array}$ \\
\hline
\end{tabular}

\section{STEP 2 b:}

Using semantic category switching and semantic category variation, construct more sentences. From the structures shown above, put works in the semanticosyntactic pattern $\mathrm{K} \Psi \Phi \cong \mathrm{SCF}$. Under this pattern, the following sentences have been obtained: He put the box down | The pupil put the books on the table. A human being (h) occupies the subject position of the sentences (he and the pupil). A non-human being (r) occupies the direct object position (the box and the books). In addition, a non-human being ( 1 and $\mathrm{r}$ ) occupies the adverbial position (down and on the table respectively).

The categories in the sentences above can occupy new positions in the sentences; this is category switching. In the same vein, new categories can occupy some positions in the sentences; this is category variation. If category switching and variation occur, we wait to see if there is change of meaning of the target word. Category switching and variation results into the following positions of the categories for the sentences above:

Category switching: Ah Br Rl, Ah Bl Rr, Ar Bh Rl, Ar Bl Rh, Al Bh Rr, Al Br Rh Category variation and switching: $\mathbf{A h} \mathbf{B r} \mathbf{R q}, \mathrm{Ah} \mathrm{Bq} \mathrm{Rr}, \mathrm{Ar} B \mathrm{~Bq}, \mathrm{Ar} \mathrm{Bq} \mathrm{Rh}$, $\mathrm{Aq} \mathrm{Bh} \mathrm{Rr}$

However, these patterns cannot yield valid sentences in terms of the word put because of category combinational constraints. However, in other cases they can (with category variation), for example, The chef $(\mathrm{h})$ put salt $\left(\mathrm{r}_{1}\right)$ in the food $\left(\mathrm{r}_{2}\right)$ | He (h) put the box (r) down (l) | She (h) put the bags (r) aside (l).

STEP 3a \& b:

Formalise the sentences in STEP $2 b$, and examine the meaning of the word by 
looking at each of the example sentences in terms of its formalisation. The sentences of put as constructed above are collected together and the meaning of put in each sentence is elicited.

He (h) put the box (r) down (l). put = to place something somewhere

The pupil (h) put the books $\left(\mathrm{r}_{2}\right)$ on the table $\left(\mathrm{r}_{1}\right)$. put = to leave something in a given place

The chef $(\mathrm{h})$ put salt $\left(\mathrm{r}_{1}\right)$ in the food $\left(\mathrm{r}_{2}\right)$. put $=$ to add something into another

She (h) put the bags (r) aside (l). put $=$ to relocate an object from one place to another

The meanings of put for instance in Procter et al. (1995) which were elicited using the corpus (Procter 1995: viii), are comparable in texture to the ones above which are elicited via the semantico-syntactic approach. Procter et al. (1995) provides the following examples: Put your clothes in the cupboard | Don't forget to put a stamp on the envelope | I need to put a new button on these trousers. | Come on, it's time to put these toys away. The conceptual meanings of put in the examples above and similar others are given in a general form, to move (something or someone) into the stated place, position or direction. Compared to Summers (1987), the psychomotor meanings of put are lumped together as having one idea. They are recorded as follows: put /put/ v put, present participle putting [T] $1[+o b j+a d v / p r e p]$ to move, set, place, lay, or fix in, on or to a stated place: Put the box on the table. $\backslash P u t$ the chair nearer the fire. | You put too much salt in this soup.| Put the toy in its box. | Put your hand over your mouth when you cough.| Put the newspaper down while I am talking to you. However, according to the semantico-syntactic approach, the meanings would be split up depending on the entities the word put is describing; e.g. to put a new button on the trousers (Procter et al. 1995), which means 'to fix something on something'.

\section{STEP 4:}

Order the meanings according to ascending complexity of semantic-syntactic patterns (valency), ascending complexity of semantic categories, alphabetical place of sub-entries and chronological order of the categories of usage labels.

In terms of arrangement of meanings, the following criteria (the alphasyntactico-semantic mode) are applied:

(i) Meanings will first be arranged according to the ascending order of semantic patterns, e.g., for put meanings were only in one pattern as:

1. to place something somewhere: He put the box down. Ah Br Rl

2. to leave something in a given place: The pupil put the books on the table. $\mathrm{Ah} \mathrm{Br}_{1} \mathrm{Rr}_{2}$

3. to add something into something: The chef put salt in the food. $\mathrm{Ah} \mathrm{Br}_{1} \mathrm{Rr}_{2}$

4. to relocate an object from one place to another: She put the bags aside. Ah Br Rl

(ii) Within semantic patterns, meanings are arranged according to the ascend- 
ing order of semantic categories, going by the categorial differences in the sentence formalisations. The semantic categories in their ascending order are: event (e), state $(\mathrm{q})$, abstract $(\mathrm{a})$; number $(\mathrm{n})$, group $(\mathrm{g})$, space $(\mathrm{l})$, temporal object (t); concrete object (r), animate (b), human (h). (e), (q) and (a) represent nonphysical entities which obtain outside space and time, e.g., write as an act. (n), (g), (l), and (t) are nonphysical entities that obtain in space and time, e.g., one as a number. (r), (b), (h) represent physical objects that happen in space and time. Each of the objects in the three subgroups as presented presupposes the other. For example, $(t$, temporal object) presupposes (l, space) in the subgroup (n), (g), (l) and (t). Of the three subgroups, the second presupposes the first, while the third presupposes the second. Therefore, the ascending order of the semantic categories is based on the principle of existential presupposition; what presupposes the other comes last.

Thus, basing on the categorial differences of the sentence formalisations in (i) above, the arrangement of the formalisations according to the ascending order of the semantic categories is as follows:

Ah Br Rl 1 add something into something: The chef put salt in the to place something somewhere: Mary put the box down.

$\mathrm{Ah} \mathrm{Br} \mathrm{Rl} 22$ to relocate an object from one place to another: He put the bags aside.

$\mathrm{Ah} \mathrm{Br}_{1} \operatorname{Rr}_{2} \quad 3 \quad$ to leave something in a given place: The pupil put the books on the table.

$\mathrm{Ah} \mathrm{Br}_{1} \mathrm{Rr}_{2} \quad 4 \quad$ to food.

(iii) Derived forms of a word, e.g. written (adj.) as in English is a written language, are arranged according to the alphabetical place of a sub-entry and entry. In the case of put there are no derived forms. Therefore, this particular criterion does not apply to the meanings of put.

(iv) Meanings that are a result of the same formalisation of sentences are arranged according to the chronological order of usage labels. The usage labels in their chronological order (determined according to what presupposes the other) are Origin (e.g. foreign origin); Time (e.g. archaic, obsolete, neologism); Status (e.g. standard, substandard); Variety (e.g. Scottish, Irish); Attitude (e.g. offensive, euphemism, disapproving); Social Group (e.g. the youth); Specialised (e.g. banking, physics, biology); Proprietary (i.e. a trademark meaning); and Medium (i.e. spoken form, written form).

Although, the following meanings in (ii) above have the same formalisation, i.e.,

$\begin{array}{ll}\text { Ah BrRl } & 1 \\ \mathrm{Ah} \mathrm{BrRl} & 2 \\ \mathrm{Ah} \mathrm{Br}_{1} \mathrm{Rr}_{2} & 3 \\ \mathrm{Ah} \mathrm{Br}_{1} \mathrm{Rr}_{2} & 4\end{array}$ 
none of them reflects the usage labels outlined above. Therefore, they will be arranged in the order in which they were elicited. However, this approach will be the source of inconsistency in the ordering of meanings, until the criterion for usage labels is further investigated.

Careful analysis of meanings in dictionaries, e.g. Summers et al. (2003), shows that meanings are categorised as meanings for simple word form (i.e. conceptual meanings), complex word form (writer), phrasal word form (put up with), compound word form (air stream), collocational word form (put on hold) and idiomatic word form (kick the bucket). The meanings of put as outlined above are only conceptual meanings. This implies that the rest of the kinds of meanings of put have not been arrived at using this method. However, one finds such meanings in dictionaries compiled using the corpus method. They are also the ones that are mostly arrived at in dictionaries compiled using the fieldwork methods, especially the collocational meanings. Such dictionaries do not present multiple conceptual meanings of a word due to the limitations of the fieldwork method used. The limitations include failure by informants to memorise the meanings of words to inform the interviewer, and high expenditure, that is, if a lexicographer has to use many more informants. Others are the cumbersome nature of the fieldwork method in terms of length of time involved and tediousness of the work.

5. The semantico-syntactic method and the alphasyntactico-semantic mode in Runyankore-Rukiga and Lugungu

Runyankore-Rukiga and Lugungu are among the Ugandan Bantu languages. In terms of writing, both languages fall in the category of less documented languages although Runyankore-Rukiga has quite a long history of writing than Lugungu. For instance, there is evidence of documentation of RunyankoreRukiga that dates back to the late 1950s whereas the latest in Lugungu dates back to the 1990s. However, much as Runyankore-Rukiga was documented earlier than Lugungu, it does not have sufficient documentation that supports corpus-driven methods of compiling general-purpose dictionaries. The situation is aggravated by lack of money to establish corpus-driven dictionary projects. One of the interventions, particularly on the part of generating meaning of words and arranging them in a consistent order would be to use the semanticosyntactic method and the alphasyntactico-semantic mode. The examples below adopted from Oriikiriza (2011), show how the methods work in RunyankoreRukiga and Lugungu.

\subsection{Worked example for Runyankore-Rukiga using the word okweta (v.) "to call"}

Using similar steps as in 4.3, we illustrate how the multiple meanings of the word okweta "to call" can be elicited and consistently arranged. 


\section{STEP 1:}

Find out a sentence that expresses the basic meaning of a word.

(i) The researcher in Oriikiriza (2011) asked an informant for a sentence in which the basic (or primary) meaning of okweta (v.) is expressed.

(ii) In response, the following sentence was given as: Irooko oyete Mugisha "Go and call Mugisha".

(iii) The informant was then asked for the meaning of okweta in this sentence.

(iv) The informant replied that it means okugambira omuntu ngu aije "to tell someone to come over".

(v) The researcher formalised the sentence as $\mathrm{Ah}_{1} \mathrm{Wh}_{2}$.

(vi) Based on the formalisation, the researcher identified its semantico-syntactic structure as $\mathrm{K} \psi \cong \mathrm{SC}\left(\mathrm{N}^{\prime \prime} \mathrm{S}^{\prime \prime}\right)$.

STEP 2a:

Find out the semantic-role patterns with which the target word is used

(i) With the pattern $\mathrm{K} \psi \cong \mathrm{SC}$, as in (iv) above, the researcher identified another immediate related pattern, i.e. $\mathrm{K}^{\prime} \mathrm{K} \psi \cong \mathrm{SCC}$ with its phrasal patterns: (N" N" N"), (N" N" P") and (N" N" S").

(ii) The researcher asked the informant for sentences that fit the phrasal patterns, and got the following responses:

N" N" N" Nil.

N" N" P" Omwegyesa akeeta abeegi n'efurembe "The teacher called the pupils using a whistle".

N" N" S' Nil.

The researcher identified other distant patterns related to $\mathrm{K}^{\prime} \mathrm{K} \psi \cong \mathrm{SCC}$. These were $\mathrm{K} \psi \Phi \cong \mathrm{SCF}$ with the phrasal patterns (N" N" Adv) and (N" N" $\mathrm{P})$, and $\mathrm{K}^{\prime} \psi \cong \mathrm{SCN}$ with the phrasal patterns $\left(\mathrm{N}^{\prime \prime} \mathrm{N}^{\prime \prime} \mathrm{N}\right)$ and $\left(\mathrm{N}^{\prime \prime} \mathrm{N}^{\prime \prime} \mathrm{A}\right)$. The researcher asked the informant for sentences that fit the phrasal patterns above. The responses were given as shown in italicised forms below.

$\mathrm{K} \psi \Phi \cong \mathrm{SCF}$

(N" N" Adv") Kato akeeta Kakuru aheeru "Kato called Kakuru outside".

(N" N" P") Nyineeka akeeta abantu aha bugyenyi "The head of the household invited people to a party".

$\mathrm{K}^{\prime} \psi \cong \mathrm{SCN}$

(N" N" N") Abazaire bakeeta omwana eiziina "The parents named the child".

(N" N" A") Abahinguzi bakeeta omusinzi omushema "The passers-by called the drunkard a fool".

(iii) Eliciting the Meanings of okweta (v.) in the sentences above.

The informant was asked to give the meaning of okweta (v.) in each of the sentences above. The following meanings were recorded, and formalised. 
Sentence: Irooko oyete Mugisha $\left(\mathrm{Ah}_{1} \mathrm{Wh}_{2}\right)$ "Go and call your Mugisha".

Meaning of okweta (v.): to inform someone to come over.

Sentence: Omwegyesa akeeta abeegi n'efurembe $\left(\mathrm{Ah}_{1} \mathrm{Wh}_{2} \mathrm{Rr}\right)$ "The teacher called the pupils with a whistle".

Meaning of okweta (v.): Okumanyisa abantu nari ekintu ngu kiije "To make a signal to someone or something by means of something informing them to come over".

Sentence: Kato akeeta Kakuru aheeru $\left(\mathrm{Ah}_{1} \mathrm{Wh}_{2} \mathrm{Rl}\right)$ "Kato called Kakuru outside".

Meaning of okweta (v.): okweta aheeru = okwiha omuntu omu bandi nari omu nju oine eki orikwenda kumugambira "to call someone outside $=$ to call someone from a group, or from a house when you have something you intend to tell them".

Sentence: Nyineeka akeeta abantu aha bugyenyi $\left(\mathrm{Ah}_{1} \mathrm{Wh}_{2} \mathrm{Ra}\right)$ "The head of the household invited people to a party".

Meaning of okweta (v.): okutaayaayisa abantu "to invite people to an occasion"

Sentence: Abazaire bakeeta omwana eiziina $\left(\mathrm{Ah}_{1} \mathrm{Wh}_{2} \mathrm{Ra}\right)$ "The parents named the child".

Meaning of okweta (v.): okuha omuntu na munonga omwana, eiziina "to give someone a name, especially children"

Sentence: Abahinguzi bakeeta omusinzi omushema $\left(\mathrm{Ah}_{1} \mathrm{Wh}_{2} \mathrm{Rq}\right)$ "The passers-by called the drunkard a fool".

Meaning of okweta (v.): okugamba aha muntu oku ari "to describe the behaviour of someone, or state in which someone is"

STEP 2b:

Using semantic category switching and semantic category variation, construct more sentences.

The researcher working with the informant established that semantic category variations are possible for the following patterns:

$\mathrm{K} \psi \Phi \cong \mathrm{SCF}$

(N" N" Adv") Nil.

(N" N" P") Ebaruha neekweta aha bugyenyi (Cr Wh Ra) "The letter is inviting you to a party".

Meaning of okweta (v.): okumanyisa omuntu obutumwa bwe nookoresa ekindi kintu "to inform someone by other means".

$\mathrm{K}^{\prime} \psi \cong \mathrm{SCN}$

(N" N" N") Ekyo nitukyeta 'okuramya' omu Runyankore-Rukiga (Ah Qa Re) "We call that 'okuramya' (worship) in Runyankore-Rukiga"

Meaning of okweta (v.): okumanya ekintu omu nyetegyereza eyaawe "to understand something in your own way"

Ekihandiiko tukyete 'Obuto bwangye' (Ah Qr Rq) Let us call the text "My Childhood" 
Meaning of okweta (v.): okuheereza ekintu eiziina ekitari muntu, "to give a name to a non-human entity".

(N" N" A) Nil.

STEP 3a:

Formalise the sentences (i.e. express the sentences in terms of semantic-roles and semantic categories. (This was done simultaneously in STEPS $2 a$ and $2 b$ ).

STEP 3b:

Examine the meaning of the word by looking at each of the examples in terms of its formalisation. (This was also done simultaneously in STEPS $2 a$ and $2 b$ ).

STEP 4:

Order the meanings according to ascending complexity of semantic-syntactic patterns (i.e. valency), ascending complexity of semantic categories, alphabetical place of sub-entries and chronological order of the categories of usage labels.

Based on the criteria in (i)-(iii) above, which are the breakdown of the alphasyntactico-semantic order, the meanings of okweta (v.) were arrange as follows:

(1) okumanya ekintu omu nyetegyereza eyaawe, "to understand something in your own way". Ekyo nitukyeta 'okuramya' omu Runyankore-Rukiga (Ah Qa Re) "We call that 'okuramya' (worship) in Runyankore-Rukiga"

(2) okuha omuntu namunonga omwana, eiziina, "to give someone a name, especially children" Sentence: Abazaire bakeeta omwana eiziina $\left(\mathrm{Ah}_{1} \mathrm{Wh}_{2} \mathrm{Ra}\right)$ "The parents named the child".

(3) okuheereza ekintu eiziina ekitari muntu, "to give a name to a non-human entity" Ekihandiiko tukyete 'Obuto bwangye' (Ah Qr Rq) "Let us call the text "My Childhood"

(4) okumanyisa omuntu obutumwa bwe nookoresa ekindi kintu, "to inform someone by means of another". Ebaruha neekweta aha bugyenyi (Cr Wh Ra) "The letter is inviting you to a party".

(5) okugamba aha muntu oku ari, "to describe the behaviour of someone, or manner in which someone is": Abahinguzi bakeeta omusinzi omushema $\left(\mathrm{Ah}_{1}\right.$ $\mathrm{Wh}_{2} \mathrm{Rq}$ ) "The passers-by called the drunkard a fool".

(6) okutaayaayisa abantu, "to invite people to an occasion": Nyineeka akeeta abantu aha bugyenyi $\left(\mathrm{Ah}_{1} \mathrm{Wh}_{2} \mathrm{Ra}\right)$ "The head of the household invited people to a party".

(7) okweta aheeru = okwiha omuntu omu bandi nari omu nju oine eki orikwenda kumugambira, "to call someone outside = to call someone from a group of others, or from a house when you have something you intend to tell 
them": Kato akeeta Kakuru aheeru $\left(\mathrm{Ah}_{1} \mathrm{Wh}_{2} \mathrm{Rl}\right)$ "Kato called Kakuru outside".

(8) okumanyisa abantu nari ekintu ngu kiije, "To make a signal to someone or something by means of something, informing them to come over": Omwegyesa akeeta abeegi n'efurembe $\mathrm{Ah}_{1} \mathrm{Wh}_{2} \mathrm{Rr}$ "The teacher called the pupils using a whistle".

(9) okugambira omuntu ngu aije $\mathrm{Ah}_{1} \mathrm{Wh}_{2}$ : "to inform someone to come over" | Irooko oyete Mugisha "Go and call your Mugisha".

\subsection{Example for Lugungu using the word kudya (v.) "to eat"}

In the example below, adopted from Oriikiriza (2011), the process of eliciting meanings of the word kudya (v.) is in form of an interview between the researcher and the respondent. The elicitation was made more flexible than the one in the English example put and Runyankore-Rukiga okweta (v.). This is because the respondent was not a language specialist, but knowledgeable in the language. Even in the case of the Runyankore-Rukiga example, the respondent was not so much of a language specialist, and so the rigidity of the elicitation of meanings was lessened compared to the one seen in the English example, put. Against this background, the elicitation of meanings in Lugungu was done in an interview that mirrored STEPS 1-4 in the English and RunyankoreRukiga examples. Below is the Lugungu elicitation and arrangement of meanings for the word kudya (v.)

STEP 1:

The Basic Meaning of kudya (v.) "to eat"

(i) Interviewer: Construct a simple sentence that shows the core meaning of kudya (v.)

Respondent: Badulu baadiiri bitooki byensei baabimala "Men ate all the bananas and finished them"

(ii) Interviewer: State the core meaning of kudya (v.) according to the example sentence above.

Respondent: to eat

(iii) Interviewer: Formalisation of example sentence: Badulu baadiiri bitooki byensei baabimala "Men ate all the bananas and finished them". Ah Br

(iv) Interviewer: Identification of semantico-syntactic pattern of the example sentence:

$\mathrm{K} \psi$

(v) Interviewer: Identification of the phrasal pattern of the example:

N" Adv"

N" N"

N" S' 
STEP 2a:

Find out the semantic-role patterns with which the target word kudya is used

(i) Interviewer: Basing on (iv) above, identify the immediate semantico-syntactic pattern of kudya (v.) from the semantico-syntactic patterns.

Interviewer: The pattern $\mathrm{K} \psi$ is augmentable to $\mathrm{K}^{\prime} \mathrm{K} \psi$. The pattern can be tested for meanings in the sentence form of '[somebody] [Verb] [something] [something]'

(ii) Interviewer: Based on the semantico-syntactic pattern $\mathrm{K}^{\prime} \mathrm{K} \psi$, predict that there is a second meaning of kudya (v.) in the sentence form of '[somebody] [Verb] [something] [something]'

(iii) Interviewer: Give a sentence of the form '[somebody] [Verb] [something] [something]' using kudya.

Respondent: Tito yaadiiri nduwa na nsu "Titus ate posho and fish".

(iv) Interviewer: Formalisation of example sentence: $\mathrm{Ah} \mathrm{Cr}_{1} \mathrm{Br}_{2}$

(v) Interviewer: Give the meaning of kudya (v.) as implied in the example sentence.

Respondent: Here yaadiiri denotes putting posho in the mouth, chewing and swallowing it using fish as sauce.

(vi) Interviewer: Basing on (a) above, identify the reduced semantico-syntactic pattern of kudya (v.) from the semantico-syntactic patterns.

Interviewer: The $\mathrm{K} \psi$ pattern is reducible to $\psi$. The pattern can be tested for meanings in the sentence form of '[N"] [Verb] [Nominal adjective"]' and '[N"] [Verb] [Adjective"]'. But the verb cannot fit in this pattern since it mainly supports linking verbs.

The pattern is also reducible to $\Omega$ to yield the sentence pattern [Something or Somebody] [Verb]

Therefore, it can be tested for meanings in terms of sentences in the form of

(a) [N"] [Verb] [Nominal adjective"], i.e. $\psi$

(b) [Something or Somebody] [Verb], i.e. $\Omega$

(vii) Interviewer: Based on the semantico-syntactic pattern $\psi$ and $\Omega$, predict that there other meanings of kudya (v.) in the sentence forms of

(a) [N"] [Verb] [Nominal adjective"], i.e., $\psi$

(b) [Something or Somebody] [Verb], i.e., $\Omega$

(viii) Interviewer: Give the following forms of sentences using kudya (v.)

(a) [N"] [Verb] [Nominal adjective"]

(b) [Something or Somebody] [Verb]

Respondent:

(a) [N"] [Verb] [Nominal adjective"], kudya (v.) does not fit in this pattern, because it is not a linking verb. 
(b) [Something or Somebody] [Verb], Mwana adyambe "The child eats"

(ix) Interviewer: Formalisation of example sentence(s)

[Something or Somebody] [Verb], Mwana adyambe "The child eats", Wh

(x) Interviewer: Give the meaning of kudya (v.) as implied in the example sentences.

Respondent:

[Something or Somebody] [Verb], Mwana adyambe "The child eats", Wh, Here adyambe means habitual eating of food.

STEP 2b:

Using semantic category switching and semantic category variation, construct more sentences using the word kudya (v.).

Interviewer: In what different ways can you meaningfully vary the entities in the sentences above in STEP 1 and $2 b$ ? The sentences are repeated here below with guiding instructions:

(i) For the sentence Tito yaadiiri nduwa na nsu (Titus ate posho with fish), construct other Lugungu sentences which mean [something (not a humanbeing)] [ate] [something] with [something].

(ii) Based on the sentence, Badulu baadiiri bitooki byensei baabimala (Men ate all the bananas); construct other Lugungu sentences which express [something (not a human being)] [ate] [something], and indicate the meaning of kudya in that context.

(iii) For the sentence Mwana adyambe (the child eats), construct other Lugungu sentences which show that [something (not human)] [Verb] using kudya, and indicate its meaning in that context.

Respondent:

Response to the first question: NIL. The respondent did not readily find the needed construction.

Response to first question: Mbwene gyadiiri mbuli "A dog ate meat." Contextual meaning of kudya:

Response to second question: The pattern [something (not human-being or animal)] [verb] [something] is not applicable in Lugungu.

However, the interviewer noticed that the respondent failed to arrive at the meaning "to each" which was expected for pattern above. Therefore, the interviewer asked the respondent as below.

Interviewer: What does kudya mean in each of the following context: Mubiri gukundya "The body itches me.", Deeru twadiiri nyama "Today we ate meat".

Respondent: kudya in Mubiri gukundya "The body itches me" denotes pain. Kudya in Deeri twadiri nyama "Today we ate meat" denotes eating meat. 


\section{STEP 3a:}

(Formalise the sentences (i.e. express the sentences in terms of semantic-roles and semantic categories. This was done simultaneously in STEPS 2a \& b above.

STEP 3b: Examine the meaning of the word by looking at each of the examples in terms of its formalisation. This also was done simultaneously in STEP 2a \& b above.

\section{STEP 4:}

Ordering the meanings of kudya (v.) according to ascending complexity of semantic-syntactic patterns (i.e. valency), ascending complexity of semantic categories, alphabetical place of sub-entries and chronological order of the categories of usage labels.

Interviewer: Collect and arrange the meanings together according to the alphasemantico-syntactic order.

Six meanings were obtained under the patterns: $\Omega, \mathrm{K} \psi$ and $\mathrm{K} \psi \Phi$. The interviewer had to figure out the meanings because, from the responses, the meanings were not straightforward. The meanings are sequenced below:

(1) to have the ability to eat: Omwana adyambe "The child eats", Wq

(2) to take in something for a meal: Deeru twadiiri nyama "Today we ate meat", $\mathrm{Ah} \mathrm{Br}$

(3) to consume something: Badulu baadiiri bitooke byensi baabimala "Men ate all the bananas and finished them" $\mathrm{Ah} \mathrm{Br}$

(4) to devour: Mbwene gyadiiri mbuli "A dog ate a goat", $\mathrm{Ab} \mathrm{Br}$

(5) to itch: Mubiri gukundya "The body itches me", $\mathrm{Cr}$ Bh

(6) kudya (ekintu) na (ekindi) chewing and swallowing one type of food with

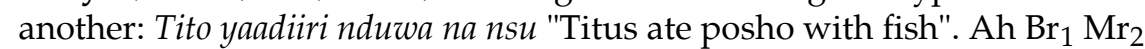

\subsection{Observation on the Worked Examples}

From the Runyankore-Rukiga worked example for the word okweta (v), nine meanings were generated and consistently arranged. For Lugungu, six meanings for the word kudya (v.) were generated and consistently arranged. Consequently, several more conceptual meanings are realised. As noted in section 4.1 , these meanings result from sense and reference. If one were to add the usage and utterance meanings to these meanings, the set of all the meanings would be bigger.

\section{Related works}

Basic meaning and extended meanings as concepts are also discussed in the work of Pustejovsky and Rumshisky (2010) as well as Hanks (2013). Pustejovsky and Rumshisky (2010: 75) call the basic meaning an 'anchor sense' from 
which extended meanings are derived. Thus, in order to describe the sense extension mechanisms, we must assume, in a set of senses for a predicate, that one sense is an anchor, and the others are related through some transformations ... we are interested in identifying the formal mechanisms through which anchor sense(s) are extended to produce related senses.

Examples of mechanisms for meaning extension as identified in Pustejovsky and Rumshisky (2010: 74, 78-79, 82-83) are described below (with illustrations and analyses from the same work):

(1) entity characteristics: Different entities in the same argument structure, influence a distinctive meaning of the verb.

John killed the plant; CAUSE-TO-DIE (THING, ANIMATE). Mary killed the conversation; TERMINATE (HUMAN, EVENT)

(2) Scalar attributes: A predicate whose complement is a phrase expressing the level or scale will yield a metaphorical meaning. Whereas there is no metaphorical meaning expressed by the verb in The plane arrived in New York on time, there is one expressed by the verb in The plane arrived at a cruising altitude of 30,000 feet. Here, arrive at has a distinctive meaning according to Pustejovsky and Rumshisky (2010). It is a multiword verb compared to arrive.

(3) Partitive connection: A predicate which expresses a partitive connection will carry a metaphorical meaning, depending on arguments with which it is used in a sentence. For instance, compared to The boat anchored several miles away, the word anchor in A written constitution must be anchored in the idea of universal citizenship has a metaphorical meaning.

This conceptualisation of how words gain meaning can be subsumed under sense and reference in the sections under the situation-role theory explained above.

The work in Hanks (2013: 105), exposes the reader to the corpus-driven methods of identifying meanings of words. Thus, ... different lexical sets in different syntactic roles can alter the meaning of the target word. This suggests that corpus analysis procedures for identifying lexical sets as clues for disambiguation are likely to be highly productive .... (Hanks 2013: 105). As already noted in the earlier sections of this paper, corpus-driven methods of identifying and arranging meanings of words in less documented languages for purposes of dictionary compilation can be affected by limited written materials from which the corpus is generated. In such cases, it is feasible to use the mental screen basing on the semantic-syntactico-method and the alphasyntactico-semantic mode, to generate meanings of words and to arrange them consistently in dictionary form.

\section{Conclusion}

The semantico-syntactic method of elicitation of meanings of words and the alphasyntactico-semantic mode of arrangement of the meanings help lexicographers to compile good dictionaries in less documented languages. Good dic- 
tionaries help to meet the meaning expectations of the prospective users of a given dictionary. Therefore, the semantico-syntactic method of elicitation of meanings of words and the alphasyntactico-semantic mode of arrangement of the meanings are approaches of dictionary-making whose end results meet such expectations. These are inter alia, conceptual meanings of words and consistent arrangement of the meanings.

\section{References}

Brown, K. and J. Miller. 1980. Syntax: A Linguistic Introduction to Sentence Structure. London/New York: Routledge.

Hanks, P. 2013. Lexical Analysis: Norms and Exploitations. Cambridge, Mass.: The MIT Press.

Kiango, J.G. 2000. Bantu Lexicography: A Critical Survey of the Principles and Process of Constructing Dictionary Entries. Tokyo: Institute for the Study of Language and Cultures of Asia and Africa (ILCAA).

Kiingi, K.B. 2008. The Semanticosyntactic Bridge I. Available from: <http://www.luganda.canadianwebs. com> (accessed 10 September 2008).

Kiingi, K.B. 2009. The Semanticosyntactic Bridge I. Available from: <http://www.luganda.canadianwebs. com> (accessed 10 September 2009).

Landau, S.I. 1989. Dictionaries: The Art and Craft of Lexicography. New York: Cambridge University Press.

Larson, Richard and Gabriel Segal. 1995. Knowledge of Meaning: An Introduction to Semantic Theory. Original edition. Cambridge, Mass.: MIT Press.

Le Veux, R.P. 1917. Premier essai de vocabulaire luganda-francais d'après l'ordre étymologique. MaisonCarrée, Algiers: Imprimerie des Missionnaires d'Afrique (Peres Blancs).

Oriikiriza, C. (Ed.). 2007. Kashoboorozi y'Orunyankore-Rukiga. (Runyankore-Rukiga Dictionary.) Kampala: Fountain Publishers.

Oriikiriza, C. 2011. Elicitation and Arrangement of Meanings of Words in the Lexicography of Bantu Languages. Unpublished Doctoral Thesis. Makerere University, Kampala.

Procter, P. et al (Eds.). 1995. Cambridge International Dictionary of English (ed. 1996, Reprint 1999). Cambridge: Cambridge University Press.

Pustejovsky, J. and A. Rumshisky. 2010. Mechanisms of Sense Extension in Verbs. De Schryver, G.-M. (Ed.). 2010. A Way with Words: Recent Advances in Lexical Theory and Analysis. A Festschrift for Patrick Hanks: 67-88. Kampala: Menha Publishers.

Singh, R.A. 1991. An Introduction to Lexicography (Reprint 1991). Mysore, India: Central Institute of Indian Languages (C.I.I.L).

Soanes, C. (Ed.). 2001. Oxford Dictionary of Current English. Third edition. Oxford: Oxford University Press.

Summers, D. (Ed.). 1987. Longman Dictionary of Contemporary English. New edition. Harlow: Longman.

Summers, D. et al. (Eds.). 2003. Longman Dictionary of Contemporary English: The Living Dictionary. Fourth edition. Harlow: Pearson Education.

Taylor, C. 1959. A Simplified Runyankore-Rukiga-English and English-Runyankore-Rukiga Dictionary. Kampala: The Eagle Press, EALB.

TUKI (Taasisi ya Uchunguzi wa Kiswahili). 1981. Kamusi ya Kiswahili Sanifu. Dar es Salaam: Oxford University Press and Institute of Kiswahili Research (IKR/TUKI), University of Dar es Salaam. 